\title{
ANALISIS PENERAPAN PSAP NO. 07 TENTANG AKUNTANSI ASET TETAP PADA KANTOR BADAN DIKLAT PEMERINTAH PROVINSI SULAWESI UTARA
}

\author{
Fresly Kornelius Engka ${ }^{1}$, Jantje J. Tinangon ${ }^{2}$, Heince R. N. Wokas ${ }^{3}$ \\ ${ }^{1,2,3}$ Fakultas Ekonomi dan Bisnis, Jurusan Akuntansi, Universitas Sam Ratulangi, Jl. Kampus Bahu, Manado, \\ 95115, Indonesia
}

E-mail : fresly.engka@gmail.com

\begin{abstract}
Statement of Government Accounting Standards (PSAP) 07 is the standard for the accounting of fixed assets include the recognition, the determination of the carrying value, the accounting treatment of the revaluation and impairment of the carrying (carrying value) of fixed assets. Fixed assets have a very important role and should be managed well in order to produce reliable information in the financial statements. This study aims to determine the suitability of adoption of a PSAP 07 on fixed asset accounting in the Kantor Badan DIKLAT Provinsi Sulawesi Utara. The method used is descriptive analysis method. The results showed Badan DIKLAT in the application of accounting of fixed assets, namely the classification, recognition, measurement / assessment, depreciation record, expenses after the acquisition, termination and release, as well as the disclosure is in accordance with the PSAP 07, but is need to know, Badan DIKLAT use SIMDA application to record the depreciation fixed asset. Keywords : Aplication, Analysis, PSAP 07, Fixed Asset
\end{abstract}

\section{PENDAHULUAN}

\subsection{Latar Belakang}

Indonesia sebagai bagian dari masyarakat dunia memiliki kewajiban untuk secara terus-menerus berpartisipasi dalam mewujudkan tata pemerintahan yang baik (good governance). Instansi pemerintah dalam menjelaskan tugasnya memerlukan laporan akuntansi, baik sebagai dasar analisis maupun untuk meningkatkan mutu pengawasan dan pengelolaan keuangan.Peraturan Menteri Dalam Negeri Republik Indonesia Nomor 64 Tahun 2013 tentang Penerapan Standar Akuntansi Pemerintahan Berbasis Akrual Pada Pemerintah Daerah Pasal 4 Ayat 4 menjelaskan bahwa kebijakan akuntansi pemerintah daerah berlaku bagi entitas akuntansi dan entitas pelaporan pemerintah daerah.

Dalam tatanan pemerintahan Sulawesi Utara, Badan Pendidikan dan Pelatihan (DIKLAT) memiliki total jumlah aset yang nilainya besar, sehingga untuk mewujudkan pemerintahan yang baik, maka sudah seharusnya Badan DIKLAT Pemerintah Provinsi Sulawesi Utara melakukan perlakuan aset tetap dengan benar. Aset tetap yang berada dibawah penguasaan suatu instansi harus dicatat secara akuntansi berdasarkan Standar Akuntansi Pemerintahan. Pengelolaan aset tetap intansi pemerintah diatur dalam Pernyataan Standar Akuntansi Pemerintahan No 07 tentang Akuntansi Aset Tetap. Aset tetap menurut PSAP 07 adalah aset berwujud yang mempunyai masa manfaat lebih dari 12 (dua belas) bulan untuk digunakan, atau dimaksudkan untuk digunakan, dalam kegiatan pemerintah atau dimanfaatkan oleh masyarakat umum. Berdasarkan uraian diatas, penulis tertarik untuk melakukan penelitian dengan judul "Analisis Perapan PSAP No. 07 Tentang Akuntansi Aset Tetap Pada Kantor Badan DIKLAT Pemerintah provinsi Sulawesi Utara."

\subsection{Tujuan Penelitian}

Adapun tujuan yang ingin dicapai dalam penelitian ini adalah untuk mengetahui kesesuaian penerapan pernyataan standar akuntansi pemerintah (PSAP) No. 07 tentang akuntansi aset tetap pada kantor Badan DIKLAT Provinsi Sulawesi Utara. 


\section{TINJAUAN PUSTAKA}

\subsection{Akuntansi Pemerintah}

Sitorus menyatakan akuntansi pemerintahan merupakan suatu proses sistematik pengelolaan keuangan pemerintah mulai dari bukti transaksi sampai ke proses pelaporan keuangan serta pertanggungjawaban kepada publik.

\subsection{Konsep Akuntansi Pemerintah}

Materi Pelatihan Akuntansi Keuangan Daerah dan SKPD (2014:9). Menjelaskan tentang konsep dasar akuntansi pemerintahan sebagai berikut.

\section{Lingkungan Akuntansi Pemerintahan}

Lingkungan operasional organisasi pemerintah berpengaruh terhadap karakteristik dan tujuan akuntansi dan pelaporan keuangannya. Ciri-ciri penting lingkungan pemerintah yang perlu dipertimbangan dalam menetapkan tujuan akuntansi dan pelaporan keuangan adalah sebagai berikut : (1) Ciri utama struktur pemerintahan dan pelayanan yang diberikan; (2) Ciri keuangan Pemerintah yang bagi pengendalian.

2. Peran Laporan Keuangan

Laporan keuangan yang berkualitas harus memenuhi kriteria yang memadai yaitu memiliki relevansi, dapat diandalkan, dapat dinilai atau dibandingkan, dan dapat dipahami (Nasrudin, 2015). Laporan keuangan pemerintah daerah adalah suatu bentuk pertanggungjwaban pemerintah daerah kepada stakeholder yang didalamnya yang mencakup berbagai macam pekerjaan yang membutuhkan keuangan, termasuk komponen aset yang tercermin dalam neraca daerah dimana setiap tahun dibuatkan laporannya setelah pelaksanaan anggaran (Erizul \& Yuliana, 2014).

\subsection{Konsep Standar Akuntansi Pemerintah}

PP Nomor 71 Tahun 2010 tentang Standar Akuntansi Pemerintahan (SAP) menyatakan bahwa SAP adalah prinsip-prinsip akuntansi yang diterapkan dalam menyusun dan menyajikan laporan keuangan pemerintah. Dalam PP 71 Tahun 2010 tentang Standar Akuntansi Pemerintahan terdapat 3 (tiga) Lampiran yaitu: Lampiran I tentang Standar Akuntansi Pemerintahan Berbasis Akrual; Lampiran II tentang Standar Akuntansi Pemerintahan Berbasis Kas Menuju Akrual; dan Lampiran III tentang Proses Penyusunan Standar Akuntansi Pemerintahan Berbasis Akrual.

\subsection{Aset Tetap}

Aset tetap merupakan salah satu unsur yang harus dikelola dengan baik agar menghasilkan informasi yang andal dalam laporan keuangan daerah (Kolinug 2015). Aset tetap dapat diperoleh dengan berbagai cara seperti pembelian, pertukaran, leasing, pembangunan sendiri dan hibah (Kirana, 2013). Aset tetap adalah aset yang memiliki wujud fisik dan memberikan manfaat ekonomi kepada entitas bisnis selama lebih dari satu periode akuntansi pada masa-masa yang akan datang (Purba, 2013:2).

\subsection{Penelitian Terdahulu}

Akhyar (2015) dalam penelitian berjudul Analisis Perlakuan Akuntansi Aset Tetap Pada Dinas Pekerjaan Umum (PU) Provinsi Sulawesi Utara. Hasil penelitian menunjukkan kebijakan akuntansi yang berlaku di Dinas Pekerjaan Umum Prov. Sulawesi Utara merujuk pada PP No. 24 Tahun 2005 dengan basis akutnansi yang digunakan yakni Cash Toward Accrual (CTA).

Dian (2013) dalam penelitian berjudul Evaluasi perlakuan akuntansi aset tetap PSAP No. 07 pada Dinas Pendapatan Pengelolaan Keuangan dan Aset Daerah Kota Tangerang 
Selatan. Hasil penelitian menunjukkan Aset Tetap pada dinas tersebut telah sesuai dengan yang tertuang pada PSAP No. 07.

\section{METODE PENELITIAN}

\subsection{Jenis dan sumber data}

Penelitian ini meneliti dua jenis data, yakni, data kualitatif yaitu penjelasan mengenai aset tetap berdasarkan teori yang bersumber dari berbagai literatur dan wawancara. Subjek dari penelitian ini adalah Kepala Badan DIKLAT Provinsi Sulut Pemerintah Provinsi Sulawesi Utara ataupun Pengelola Aset Tetap,sehingga penelitian berupa opini, sikap, dan pengalaman pelaksana tersebut merupakan data subjek. Serta, data kuantitatif yang digunakan adalah data keuangan dan sejumlah laporan mengenai pencatatan aset tetap yang dilakukan oleh Badan DIKLAT Pemerintah Provinsi Sulawesi Utara.

Sumber data menggunakan data primer yag diperoleh dan dikumpulkan dengan cara melakukan penelitian langsung pada Kantor Badan DIKLAT pemerintah Provinsi Sulawesi Utara.

\subsection{Data dan teknik pengambilan data}

Metode yang digunakan dalam pengumpulan data untuk penelitian ini adalah sebagai berikut:

1. Teknik Wawancara

Teknik ini dilakukan dengan cara bertanya langsung kepada staf dan pimpinan dalam memperoleh data yang diperlukan dalam penelitian ini.

2. Teknik Dokumentasi

Teknik ini dilakukan dengan cara mendapatkan informasi dari buku-buku literatur, majalah, jurnal serta bahan-bahan informasi lainnya yang berhubungan dengan maslah yang diteliti.

\subsection{Metode analisis}

Sugiyono (2011) menjelaskan bahwa metode analisis adalah metode yang digunakan untuk menggambarkan dan menganalisis suatu hasil penelitian tetapi tidak digunakan untuk membuat kesimpulan yang lebih luas. Metode yang digunakan dalam penelitian ini adalah metode analisis deskriptif yaitu suatu metode pembahasan permasalahan yang sifatnya menguraikan, menggambarkan, membandingkan, dan menerangkan suatu data. Analisis data dilakukan dengan cara sebagai berikut.

a. Mengumpulkan data kualitatif dan kuantitatif, mempelajari sejarah Badan DIKLAT Provinsi Sulawesi Utara, struktur organisasi dan tupoksi Badan DIKLAT Provinsi Sulawesi Utara, metode pelaporan keuangan yang baik, peraturan-peraturan dan kebijakan pengelolaan aset tetap yang berlaku umum, dan kebijakan pemerintah setempat yang telah diterapkan dalam pengelolaan aset tetap.

b. Membandingkan hasil yang diperoleh dengan literatur yang berhubungan dengan penelitian untuk dijadikan dasar acuan dalam kelengkapan dokumen sumber. Dalam hal ini peneliti mencoba untuk mengkaji berdasarkan Pernyataan Standar Akuntansi Pemerintahan No. 07 tentang Akuntansi Aset Tetap.

c. Menarik kesimpulan.

\section{HASIL ANALISIS DAN PEMBAHASAN}

\subsection{Hasil analisis}

\subsubsection{Kebijakan Akuntasi}

Kebijakan akuntansi yang berlaku di Badan DIKLAT Provinsi Mengacu pada Peraturan Gubernur Sulawesi Utara No 30 Tahun 2014 tentang Kebijakan Akuntansi 
Pemerintah Provinsi Sulawesi Utara. Penyusunan Laporan Keuangan untuk tahun yang berakhir tanggal 31 Desember 2015 berdasarkan asumsi bahwa:

a) Badan DIKLAT Pemerintah Provinsi Sulawesi Utara merupakan organisasi yang mandiri dan menjadi pusat pertanggungjawaban yang harus bertanggungjawab atas pelaksanaan tugasnya sesuai dengan peraturan perundang-undangan yang berlaku atau sebagai entitas pelaporan.

b) Berarti bahwa Setiap kejadian atau transaksi yang disajikan dalam laporan keuangan dapat dinilai dengan satuan uang, berdasarkan asumsi keterukuran dalam satuan uang.

Laporan Keuangan Badan DIKLAT Pemerintah Provinsi Sulawesi Utara Tahun Anggaran 2015 disusun mengacu pada Standar Akuntansi Pemerintah (PP 71 Tahun 2010). Basis akuntansi yang digunakan dalam laporan keuangan Badan DIKLAT Provinsi Sulawesi Utara adalah basis akrual untuk pengakuan pendapatan LRA, belanja, dan pembiayaan dalam Laporan Realisasi Anggaran,dan untuk pengakuan pendapatan LO, beban dalam laporan operasional serta aset, kewajiban, dan entitas dalam Neraca.

Menurut pengelola aset tetap di badan DIKLAT sulut Aset tetap pada Badan DIKLAT Provinsi Sulut memiliki pengertian yang sama dengan pengertian aset tetap dalam Pernyataan Standar Akuntansi Pemerintahan (PSAP) No. 07, yaitu aset berwujud yang mempunyai masa manfaat lebih dari 12 (dua belas) bulan untuk digunakan dalam kegiatan pemerintah daerah atau dimanfaatkan oleh masyarakat umum.

\subsubsection{Klasifikasi Aset Tetap}

Aset tetap diklasifikasikan berdasarkan kesamaan dalam sifat atau fungsinya dalam aktifitas operasi entitas yang terdiri dari tanah, peralatan dan mesin, gedung dan bangunan; jalan, irigasi, dan jaringan; aset tetap lainnya; dan konstruksi dalam pengerjaan. Rincian dari masing-masing aset tersebut sudah tercantum dalam Kartu Inventaris Barang (KIB).

\subsubsection{Pengakuan Aset Tetap}

Kantor Badan DIKLAT Provinsi Sulawesi Utara, suatu aset diakui sebagai aset tetap jika aset tersebut mempunyai wujud, masa manfaat lebih dari 12 (dua belas) bulan, biaya perolehan dapat diukur secara andal, tidak untuk dijual, dan diperoleh atau dibangun dengan maksud untuk digunakan (Pengelola aset tetap Badan DIKLAT Pemprov Sulut). Untuk mendukung keandalan pengakuan aset tetap, maka aset tetap harus disertai dengan berita acara serah terima aset terima aset tetap. Adanya berita acara serah terima aset tetap tersebut menandakan pihak Badan DIKLAT Provinsi Sulawesi Utara sudah berhak menggunakan dan mengelola aset tetap yang telah diserahkan.

\subsubsection{Pengukuran/Penilaian Aset Tetap}

Badan DIKLAT dalam pengukurannya terhadap Aset tetap menggunakan biaya perolehan, apabila penilaian aset tetap dengan menggunakan biaya perolehan tidak memungkinkan maka nilai aset tetap didasarkan pada nilai wajar pada saat perolehan atau menggunakan harga pasar berikut penuturan Pengelola aset tetap Badan DIKLAT. Menurut pengelola aset tetap di kantor Badan DIKLAT setelah diwawancarai biaya perolehan terdiri dari keseluruhan biaya yang digunakan untuk perolehan aset tetap sampai siap pakai, tetapi untuk tanah, diukur dengan niai penyerahan aset tetap tersebut kepihak Badan DIKLAT. Biaya perolehan peralatan dan mesin terdiri dari harga beli, pajak, dan biaya lain-lain sampai siap digunakan.

\subsection{Pembahasan}

\subsubsection{Perbandingan Klasifikasi Aset Tetap}

Berdasarkan Tabel perbandingan klasifikasi aset tetap pada Badan DIKLAT SULUT digolongkan berdasarkan kesamaan sifat atau fungsinya dalam aktivitas, sehingga klasifikasi aset tetap pada Badan DIKLAT telah sesuai dengan peraturan permerintah yang berlaku yaitu 
peraturan pemerintah N0. 71 Tahun 2010 Pernyataan Standar Akuntansi Pemerintah (PSAP) NO.07 tentang akuntansi aset tetap.

\subsubsection{Perbandingan Pengakuan Aset Tetap}

Berdasarkan tabel pengakuan aset tetap oleh Badan DIKLAT SULUT telah sesuai dengan peraturan pemerintah yang berlaku yaitu Peraturan Pemerintah No. 07 tentang akuntansi aset tetap. Aset tetap pada Badan DIKLAT harus lebih dari dua belas bulan, diakui menggunakan biaya perolehan, maksud pengadaan aset tetap bukan untuk dijual melainkan untuk digunakan dalam menunjang kegiatan operasional, dan aset tetap diakui pada saat transaksi atas aset tetap itu terjadi.

\subsubsection{Perbandingan Pengukuran/Penilaian Aset Tetap}

Berdasarkan Tabel pengukuran/penilaian aset tetap oleh Badan DIKLAT SULUT menggunakan biaya perolehan yaitu biaya yang dikeluarkan aset tetap sampai siap untuk digunakan oleh Badan DIKLAT. Biaya perolehan tersebut terdiri dari harga beli, pajak, biaya angkut, dan biaya instalasi yang dikeluarkan untuk Aset tetap tersebut sehingga telah sesuai dengan peraturan pemerintah yang berlaku yaitu, Peraturan Pemerintah No. 71 2010, Pernyataan Standar Akuntansi Pemerintahan (PSAP) No. 07 tentang akuntansi aset tetap.

\subsubsection{Perbandingan Pengeluaran Setelah Perolehan Aset Tetap}

Berdasarkan Tabel pengeluaran setelah perolehan untuk perbaikan suatu aset tetap Badan DIKLAT SULUT mengacu pada kebijakan nilai satuan minimum kapitalisasi Pemerintah Daerah Sulawesi Utara yaitu Peraturan Gubernur Nomor 30 tahun 2014. Hal ini telah sesuai dengan peraturan pemerintah No. 71 Tahun 2010, Pernyataan Standar Akuntansi Pemerintahan (PSAP) No. tentang akuntansi aset tetap.

\subsubsection{Perbandingan Penyusutan Aset Tetap}

Berdasarkan Tabel nilai akumulasi penyusutan per 31 desember 2016 tidak dikelola oleh BADAN DIKLAT melainkan aplikasi SIMDA dari Badan pengelola barang milik daerah (BPK-BMD). Dengan aplikasi ini Badan Diklat Mempermudah dan menghemat waktu perhitungannya.

\subsubsection{Perbandingan Pengungkapan Aset Tetap}

Pada Badan Diklat Pemprov Sulut, metode yang dipakai untuk menghitung penyusutan adalah metode garis lurus (straight line metode) pernyataan ini sesuai dengan catatan atas Laporan keuangan oleh Badan DIKLAT Provinsi Sulawesi Utara tahun 2016 yang tertulis menggunakan metode garis lurus.Berdasarkan tabel pengungkapan aset tetap oleh Badan DIKLAT Provinsi Sulawesi Utara telah sesuai dengan PSAP No. 07. Pernyataan Standar Akuntansi aset tetap. Badan DIKLAT mengungkapkan dasar penilaian yang digunakan untuk menentukan nilai tercatat dalam laporan keuangan, terdapat informasi penyusutan, hingga kebijakan akuntansi kapitalisasi yang berkaitan dengan aset tetap.

\section{KESIMPULAN DAN SARAN}

\subsection{Kesimpulan}

Berdasarkan hasil penelitian dan pembahasan yang dilakukan dalam menganalisis penerapan Pernyataan Standar Akuntansi Pemerintahan (PSAP) No. 07 tentang akuntansi aset tetap pada Badan DIKLAT Pemerintah Provinsi Sulawesi Utara, maka dapat diambil kesimpulan bahwa Badan DIKLAT dalam Pengklasifikasian, Pengakuan, Pengukuran/penilaian, pengeluaran setelah perolehan, penyusutan, Penghentian dan pelepasan, dan pengungkapan aset tetap telah sesuai dengan Pernyataan Standar Akuntansi Pemerintahan (PSAP) Nomor 07.

\subsection{Saran}

Berdasarkan hasil penelitian dan pembahasan yang dilakukan dalam menganalisis penerapan PSAP No. 07 tentang akuntansi aset tetap pada Badan DIKLAT Pemerintah 
Provinsi Sulawesi Utara, maka penulis mengharapkan Badan DIKLAT Pemerintah Provinsi Sulawesi Utara dalam penyusunan dan perhitungan aset tetap juga mengetahui secara teknis penyusunan manualnya karena saat ini hanya menggunakan aplikasi SIMDA dari Badan Pengelola Barang Milik Daerah (BP-BMD).

\section{DAFTAR PUSTAKA}

Auliana, 2014.Analisis Akuntansi Aset Tetap Pada Badan Penanggulangan Bencana Daerah Kota Tanjungpinang Berdasarkan Pernyataan Standar Akuntansi Pemerintahan No 07.Skripsi (tidak dipublikasikan). Fakultas Ekonomi. Universitas Maritim Raja Ali Haji: Tanjungpinang.

Afrilinda, 2015.Analisis Akuntansi Aset Tetap Pada Bank Nagari Cabang Pembantu UNP. Diploma thesis, UPT. Perpustakaan Unand. Universitas Andalas: Padang.

Effendi, R., 2015.Analisis Perlakuan Akuntansi Atas Aset Tetap Berdasarkan SAK ETAP Pada CV. Sekonjing Ogan Ilir.Volume 5.Nomor 1. Jurnal Ilmiah STIE MDP. Universitas Tridinanti Palembang: Indonesia.

Elsye, R., Suwanda, Muchidin, U., 2016. Dasar-dasar Akuntansi Akrual Pemerintah Daerah. Cetakan Pertama. Penerbit Ghalia Indonesia: Bogor.

Erizul, Yuliani, F., 2014.Pelaksanaan Pengelolaan Aset Tetap Daerah.Volume 2.Nomor 2. Halaman 115-226. Jurnal Administrasi Pembangunan. Universitas Riau: Pekanbaru.

Hanis, M H., Trigunarsyah, B., Susilawati, C., 2010. Elements of Public Asset Management Framework For Local Governments In Developing Countries. $8^{\text {th }}$ International Conference on Construction and Real Estate Management (ICCREM 2010).1-3 Desember 2010.Royal on the Park Hotel. Brisbane.

Haddadi, Mohammad H., 2014. The Study of Accumulated Depreciation And Stock Prices in Iranian Industries. Volume 2.Issue 9.The International Journal of Business \& Management. Department of Commerce and Management Islamic Azad University: Iran.

Hilmah KH, Fairoza, 2013. Analisis Pelaksanaan Penatausahaan dan Akuntansi Aset Tetap Pada DPKA Kota Padang.Volume 1.Nomor 1. Seri D. Jurnal Akuntansi. Universitas Negeri Padang: Indonesia.

Imawan, R., Wahyudin, A., 2014. Analisis Kemandirian Keuangan Daerah Provinsi Jawa Tengah Tahun Anggaran 2010-2012.Accounting Analysis Journal. Jurusan Akuntansi. Fakultas Ekonomi. Universitas Negeri Semarang: Indonesia.

Junaidi, 2015.Perlakuan Akuntansi Sektor Publik Desa di Indonesia.Volume 6.Nomor 1.Jurnal NeO-Bis.Fakultas Ekonomi dan Bisnis. Universitas Trunojoyo Madura: Jawa Timur.

Kolinug, M., Ilat, V., Pinatik, S., 2015.Analisis Pengelolaan Aset Tetap Pada Dinas Pendapatan Pengelolaan Keuangan dan Aset Daerah Kota Tomohon. Volume 3.Nomor 1. Jurnal EMBA. FEB UNSRAT: Manado.

Kirana, Putra,2013. Perlakuan Akuntansi Aset Tetap Berdasarkan PSAK No. 16 Pada PT. Graphika Beton.Jurnal UMRAH. Jurusan Akuntansi. Fakultas Ekonomi. Universitas Maritim Raja Ali Haji: Tanjung Pinang.

Langelo, F., Saerang, D. P. E., Alexander, S. W., 2015. Analisis Penerapan Standar Akuntansi Pemerintahan Berbasis Akrual Dalam Penyajian Laporan Keuangan Pada Pemerintah Kota Bitung.Volume 3.Nomor 1. Jurnal EMBA. FEB UNSRAT: Manado.

Manossoh, H., 2015. Implementasi Sistem Akuntansi Pemerintahan Dalam Mewujudkan Good Government Governance Pada Pemerintah Provinsi Sulawesi Utara.Volume 15.Nomor 05. Jurnal Berkala Ilmiah Efisiensi. FEB UNSRAT: Manado. 
Nasrudin, E., 2015. Efektivitas Sistem Informasi Manajemen dan Akuntansi Barang Milik Negara (SIMAK-BMN) Terhadap Pengelolaan Aset Negara.Volume 13.Nomor 2. Jurnal Akuntansi. Universitas Jember: Jawa Timur.

Pham, D B., 2014.Tangible Fixed Assets Accounting System for Enterprise in Vietnam.Volume 6.Nomor 6.International Journal of Economics and Finance. University of Hai Duong: Vietnam.

Purba, Marisi P., 2013.Akuntansi Keuangan Aset Tetap dan Aset Tak Berwujud. Edisi Pertama. Graha Ilmu: Yogyakarta.

Piera,Franck Missonier, 2015, Motives for Fixed Asset Revaluation: An Empirical Analysis with Swiss Data, International journal, ESSEC - Business SchoolAve Bernard Hirsch, France

Putra, T. M., 2013. Analisis Penerapan Akuntansi Aset Tetap Pada CV. Kombos Manado.Volume 1.Nomor 3. Jurnal EMBA. FEB UNSRAT: Manado.

Reeve, J., Warren, C., Duchac, J., Wahyuni, E., Soepriyanto, G., Jusuf, A., Djakman, C., 2012.Pengantar Akuntansi Adaptasi Indonesia.Buku 2.Salemba Empat: Jakarta.

Riyanto, Agus, 2015.Akuntansi Pemerintah Daerah Berbasis Akrual. Cetakan Pertama. Pustaka Pelajar: Yogyakarta.

Sawani, A., 2009. The Changing Accounting Environment: International Accounting Standards and US Implementation. Volume 1.Page 1.Journal of Finance \& Accountancy.Westminster College: Utah.

Sita, S I., 2015.Analisis Perlakuan Akuntansi Aset Tetap Pada Rumah Sakit Umum Daerah Genteng.Skripsi. Fakultas Ekonomi. Universitas Jember: Jember.

Sitorus, S., Kalangi, L., Walandouw, S., 2015.Analisis Kesiapan Penerapan Standar Akuntansi Pemerintahan Berbasis Akrual Berdasarkan PP Nomor 71 Tahun 2010 Pada Dinas Pendapatan Pengelolaan Keuangan dan Barang Milik Daerah Kota Tomohon.Volume 3.Nomor 1. Jurnal EMBA. FEB UNSRAT: Manado.

Sudaryati, Dian, 2013. Evaluasi Perlakuan Akuntansi Aset Tetap PSAP No, 07 Pada Dinas Pendapatan Pengelolaan Keuangan dan Aset Daerah Kota Tangerang Selatan. Skripsi. Jurusan Akuntansi. Fakultas Ekonomi. Universitas Pamulang: Tangerang Selatan.

Stephana Dyah Ayu R., Sih Mirmaning D. E., StLily Indarto, Agnes Ariee M., 2015. Tax Accounting for Fixed Assets: IFRS Based Indonesian Fiscal Reconsiliation. Volume .Issue 4. International journal of Humanities and Management Sciences (IJHMS). Faculty of Economic and Business Soegijapranata Catholic University: Semarang.

Sugiyono, 2011.Metode Penelitian Kuantitatif dan Kualitatif.Alfabeta Bandung.

Sunyoto, D., 2013.Metodologi Penelitian Akuntansi. Cetakan Kesatu. Refika Aditama: Bandung.

Tipan, A., Saerang, D. P. E., 2016. Analisis Perlakuan Akuntansi Aset Tetap Pada Dinas Pekerjaan Umum (PU) Provinsi Sulawesi Utara.Volume 11.Nomor 1. Jurnal EMBA. FEB UNSRAT: Manado.

Tobari,2015. Membangun Budaya Organisasi Pada Instansi Pemerintahan,Edisi 1. Cetakan 2. Deepublish: Yogyakarta.

Wardaya, M. R Rangga, K, M., Kanza, M. M., 2013 Makalah Good Governance.Jurnalistik C Semester II. Fakultas Dakwah dan Ilmu Komunikasi. UIN Sunan Gunung Djati: Bandung.

Wiratna, S., 2015.Akuntansi Sektor Publik. Penerbit Pustaka Baru Press: Yogyakarta.

Widi, Restu Kartiko, 2010. Asas Metodologi PenelitianSebuah Pengamatan Pengenalan Penelitian. Graha Ilmu: Yogyakarta.

Zhemim, Wang, 2006.Upward Revaluation of Fixed Assets. Volume 4.Number 1.Journal of Business \& Economics Research. Uninversity of Wisconsin - Parkside: Wisconsin. 